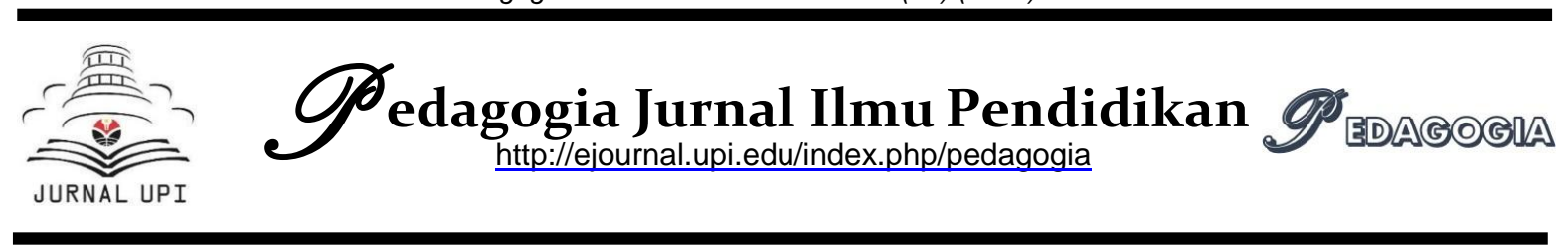

\title{
Respon Mahasiswa terhadap Pembelajaran Bahasa Inggris Berbasis Blended Learning Melalui Edmodo di Universitas Baturaja
}

\author{
Merie Agustiani \\ Sulia Ningsih \\ Anggraeni Agustin Muris \\ Fakutas Keguruan dan IImu Pendidikian \\ Universitas Baturaja \\ merie_piecery@fkip.unbara.ac.id
}

\begin{abstract}
A b stract
The Industrial Revolution 4.0 is an opportunity for language teachers to be creative in developing students' speaking skills. One creative effort that can be done is to use a blended learning model. In the Educational Technology Study Program, the use of blended learning models has been carried out in several courses. But for English language course has never been done before. Blended learning can be done with various online learning media, one of which is Edmodo. The Purpose of this research was aimed at finding out the students' responses of English learning based on blended learning through edmodo at Baturaja University. This was a quantitative descriptive study. The sample of the study was taken through total sampling method with a total of 44 students from the Education Technology Education FKIP Baturaja University in academic year 2018/2019. A questionnaire was used to collect the data and it was analyzed using descriptive analysis techniques. The results of this study indicated that $82 \%$ of the students agreed with the application of English learning based on blended learning through edmodo, and the remaining $18 \%$ did not agree with English learning based on blended learning through edmodo.
\end{abstract}

Keywords: Edmodo, Blended learning, English Learning

\begin{abstract}
A bstrak
Revolusi Industri 4.0 menjadi kesempatan untuk guru bahasa agar menjadi kreatif dalam mengembangkan kemampuan berbicara siswa. Salah satu usaha kreatif yangg dapat dilakukan adalah menggunakan model pembelajaran blended learning.i Program Studi Teknologi Pendidikan, penggunaan model pembelajaran blendedd learning telah dilakukan di beberapa mata kuliah. Namun untuk mata kuliah bahasa inggris belum pernah dilakukan sebelumnya. Blended learning ini dapat dilakukann dengan berbagai media pembelajaran online, salah satunya adalah edmodo. Penelitian ini bertujuan untuk mengetahui persepsi mahasiswa terhadap pembelajaran bahasa inggris berbasis blended learning melalui edmodo di Universitas Baturaja. Penelitian ini merupakan penelitian deskriptif kuantitatif. Sampel penelitian diambil dengan metode total sampling dengan jumlah 44 orang mahasiswa program studi Teknolologi Pendidikan FKIP Universitas Baturaja tahun akademik 2018/2019. Instrumen dalam penelitian ini menggunakan angket yang dianalisis menggunakan teknik analisis deskriptif. Hasil penelitian menunjukkan bahwa $82 \%$ setuju dengan penerapan pembelajaran bahasa inggris berbasis blended learning melalui edmodo dan sisanya $18 \%$ tidak setuju pada pembelajaran bahasa inggris berbasis blended learning melalui edmodo.
\end{abstract}

Article Info

Naskah Diterima : 2019-07-27

Naskah Direvisi: 2019-08-30

Naskah Disetujui: 2019-09-10 


\section{A. PENDAHULUAN}

Pemerintah Republik Indonesia mendorong dikembangkannya sistem informasi pendidikan berbasis teknologi dan informasi untuk memberikan akses sumber pembelajaran kepada pendidik, tenaga kependidikan dan peserta didik (Peraturan Pemerintah No 17 Tahun 2010, pasal 48 dan 59). Salah satu media pembelajaran yang menggunakan teknologi informasi dikenal sebagai $e$ learning.

Revolusi Industri 4.0 menjadi kesempatan untuk guru bahasa agar menjadi kreatif dalam mengembangkan kemampuan berbicara siswa. Guru dapat mengintegrasikan pengajaran tatap muka dengan aktivitas yang dimediasi komputer, yang saat ini dikenal sebagai "Blended learning".

Model pembelajaran blended learning yang merupakan perkembangan dari e-learing, saat ini populer di kalangan guru EFL / ESL yang diyakini bermanfaat untuk menciptakan suasana baru dan dinamis selama pembelajaran bahasa target. Melalui penggunaan blendedlearning, peserta didik dapat diberikan instruksi, mempraktekkan pengiriman pidato mereka, menerima umpan balik dari rekan-rekan dan instruktur pada garis besar pidato mereka dan pengiriman pidato yang mudah-mudahan dapat mengembangkan kemampuan lisan dan motivasi mereka dalam kelas EFL. Model ini menawarkan kepada para guru kombinasi instruksi tatap muka dengan instruksi yang dimediasi komputer atau pembelajaran online. Hal ini sesuai dengan pendapat Apriliya Rizkiyah bahwa pembelajaran dengan strategi blended learning membuat suasana baru yang menyenangkan dan peserta didik lebih mandiri dalam mengerjakan tugas ketika mengikuti pembelajaran menggunakan bended learning (Rizkiyah, 2015).

Pembelajaran online dilakukan melalui Web dan dapat mencakup teks, grafik, animasi, audio, video, papan diskusi, email, dan pengujian (Bencheva, 2010). Pembelajaran online biasanya "sesuai permintaan" dan diarahkan sendiri tetapi dapat mencakup obrolan sinkron, telekonferensi berbasis web (grafik audio), atau teknologi serupa. Dampak Teknologi Informasi dan Komunikasi (TIK) dalam pendidikan telah terbukti dalam berbagai penelitian karena memungkinkan pengajaran dan pembelajaran menjadi lebih menarik, interaktif, bermakna dan juga memotivasi. Hal ini juga dapat dilakukan oleh dosen sebagai tenaga pengajar di Perguruan Tinggi (Rodrigues \& Vethamani, 2015).

Salah satu pembelajaran berbasis blended learning adalah dengan menggunakan edmodo. Edmodo digunakan sebagai variasi atau digabung dengan pembelajaran tatap muka. Edmodo adalah sebuah portal yang menyajikan informasi dengan cara yang menarik dan memotivasi yang pada gilirannya menjadi lingkungan yang terkontrol yang cocok untuk bimbingan teman sebaya (Redman \& Trapani, 2012).

Proses perkuliahan selama ini hanya didefinisikan sebagai proses pembelajaran melalui tatap muka di kelas. Padahal, melalui suatu media yang memungkinkan belajar tanpa tatap muka, proses perkuliahan masih bisa berlangsung dan interaksi belajar antara dosen dan mahasiswa masih bisa terlaksana. Media yang bisa digunakan untuk mengatasi hal tersebut adalah media pembelajaran edmodo yang digunakan sebagai variasi dalam penerapan blended learning. Hal ini sesuai dengan pendapat Vivi Rulviana (Rulviana, 2018) bahwa fitur edmodo dapat memberikan kemudahan bagi dosen dan mahasiswa karena pembelajaran dapat dilakukan kapan dan dimanapun.

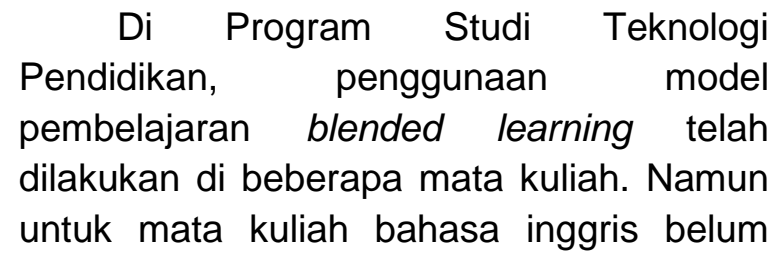


pernah dilakukan sebelumnya. Implementasi Teknologi Informasi dan Komunikasi yang paling maksimal dilakukan adalah penggunaan e-mail. Kemudian atas dasar ini peneliti menerapkan pembelajaran bahasa inggris berbasis blended learning menggunakan edmodo pada mahasiswa semester II Program Studi Teknologi Pendidikan sebagai bagian dari pembaruan dan variasi model pembelajaran. Sebagai usaha peneliti dalam melihat dampak edmodo bagi mahasiswa, peneliti berinisiatif untuk melakukan penelitian sebagai cara untuk memperoleh informasi respon mahasiswa terhadap pembelajaran bahasa inggris berbasis blended learning berbasis edmodo. Hasil penelitian ini akan dijadikan sebagai dasar bagi peneliti maupun dosen yang lain untuk memberikan keputusan selanjutnya apakah akan menggunakan edmodo atau tidak untuk menerapkan blended learning pada pembelajaran bahasa inggris.

\section{B. TINJAUAN PUSTAKA}

\section{Blended-Learning}

Blended learning merupakan sebuah pendekatan pembelajaran yang memadukan kelebihan pada pembelajaran tatap muka dan e-learning. Ide pemikiran tentang lingkungan blended learning adalah lingkungan belajar dimana guru dan siswa bekerja dengan perpaduan antara buku, presentasi dan kegiatan kelas, dan sumber daya digital termasuk materi online atau aplikasi ponsel pintar (Harmer, 2014).

Blended learning sebagai kombinasi karakteristik pembelajaran tradisional dan lingkungan pembelajaran elektronik atau Blended learning. menggabungkan aspek Blended learning (format elektronik) seperti pembelajaran berbasis web, streaming video, komunikasi audio synchronous dan asynchronous dengan pembelajaran tradisional "tatap muka" (Sjukur, 2012).

Menurut KheFoon Hew Wing Sum Cheung (Hamad, 2015) mengatakan blended learning adalah setiap saat siswa dapat belajar, karena pembelajaran blended learning adalah sebagian belajar dengan tatap muka dan sebagian dengan bantuan internet. Selain itu "Blended learning" telah digunakan untuk menggambarkan semacam pengajaran menggunakan tatap muka dan sepenuhnya pendidikan online.

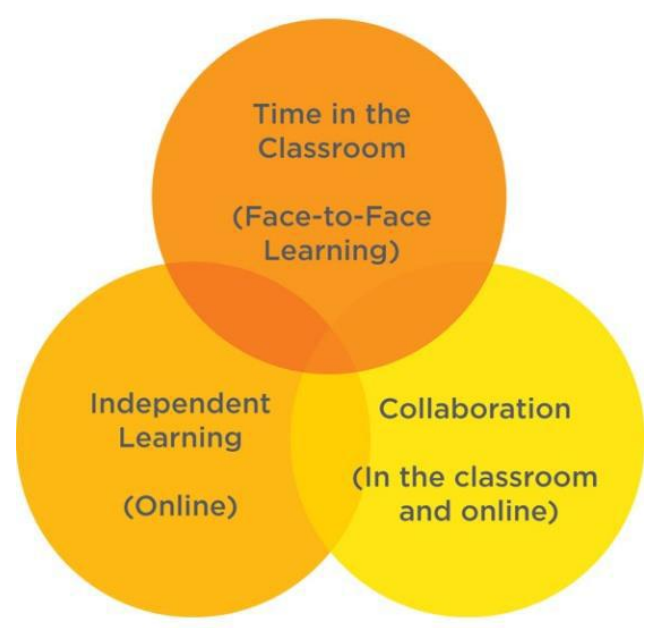

Gambar 1

Konsep Blended Learning

(Sumber : http://orangecharterschool.org/the-future-of-learning-has-arrived-at-ocs/) 
Dengan kata lain, Blended learning adalah proses pembelajaran yang mengkombinasikan pembelajan mandiri secara online dan pembelajaran tatap muka dengan memanfaatkan media dan teknologi untuk menyediakan pengalaman pembelajaran yang lebih menyenangkan dan efektif kepada peserta didik.

Adapun karakteristik utama dari blended learning menurut (Lalima, Dangwal, 2017), siswa memiliki pilihan dua mode pembelajaran, guru berpenglalam dengan kedua model pembelajaran, siswa mendapatkan dua interaksi (virtual dan tatap muka),

Siswa dalam blended learning dapat memilih mode tradisional pengajaran di kelas di mana mereka bisa mendapatkan interaksi pribadi dengan guru dan teman sekelas mereka atau mereka dapat memilih pembelajaran yang didukung TIK. Selain siswa, guru juga berpengalaman dengan kedua mode tersebut. Fitur penting dari blended learning bahwa guru sangat dinamis, ahli teknologi dan sepenuhnya terlatih untuk bekerja secara efisien baik dalam format-format kelas tradisional dan format yang didukung TIK.

\section{Edmodo}

Witherspoon menyimpulkan bahwa Edmodo dapat dilihat sebagai sebuah Learning Management System (LMS) yang dapat memfasilitasi dosen untuk membuat dan mengatur kelas online mereka secara mudah (Witherspoon, 2011). Situs ini menyediakan cara yang sederhana bagi dosen dan mahasiswa untuk terhubung dan kerjasama secara virtual.

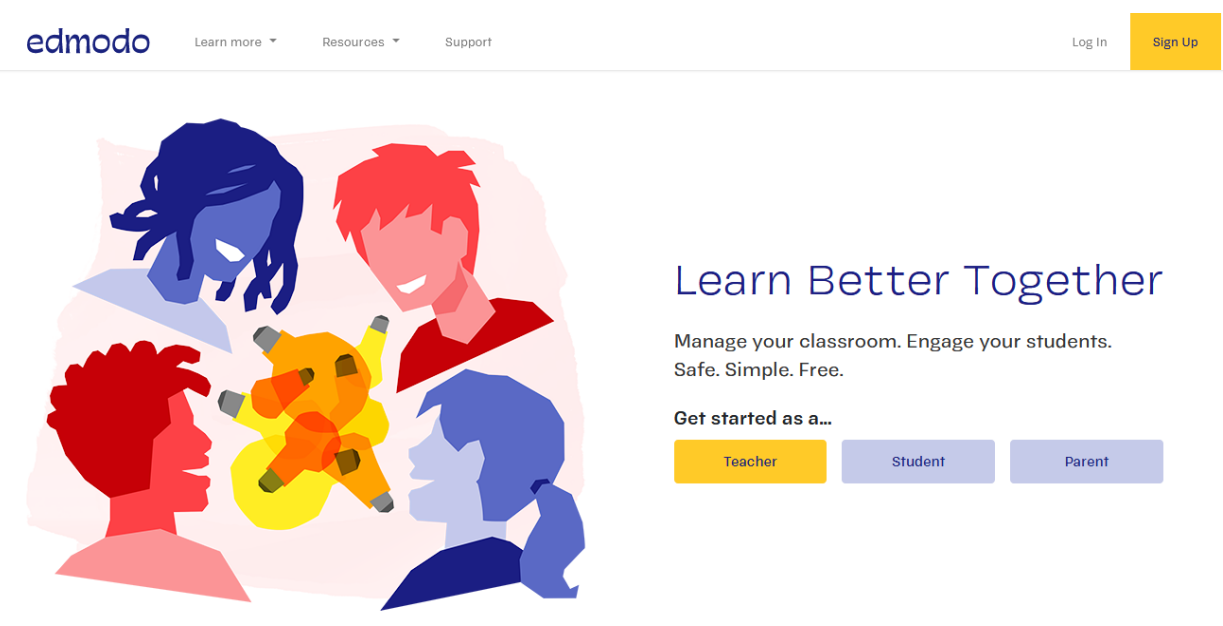

\section{Gambar 2}

Tampilan antarmuka Edmodo

Sumber : https://new.edmodo.com

Sebagai contoh, dosen dapat mengirimkan kuis dan tugas, memberikan umpan balik, menerima tugas yang diselesaikan oleh mahasiswa, memberikan penilaian, melalukan jajak pendapat, menyimpan dan membagi materi belajar dalam bentuk file maupun tautan (link), maupun mengirimkan pesan atau peringatan kepada seluruh peserta grup belajar. Edmodo merupakan platform pembelajaran sosial gratis yang memungkinkan siswa mengakses konten yang diunggah oleh guru. Platform ini memungkinkan guru dan siswa untuk berkomunikasi satu sama lain melalui pesan, sehingga memberikan kesempatan kepada peserta didik untuk berkomunikasi dan berkolaborasi dalam lingkungan 
kelas virtual. Balasubramanian, Jaykumar \& Fukey, 2014; Ekmekçi, 2016; Mokhtar, 2017).

Edmodo adalah jaringan media sosial yang dimanfaatkan dalam pembelajaran secara online. Jaringan ini dianggap aman untuk digunakan dalam pembelajaran kelas online. Penggunaan media sosial online ini memungkinkan interaksi berlangsung tanpa batas ruang dan waktu. Guru, siswa, dan orang tua dapat berinteraksi dengan menggunakan Edmodo. Guru dapat memposting tugas atau latihan dan quiz. Siswa dapat mengirim tugas, pekerjaan rumah atau latihan juga. Siswa, guru, dan orang tua dapat melihat nilai. Edmodo sangat bermanfaat dalam aktivitas pembelajaran karena dapat mendorong

interaksi sosial dimana siswa dapat mengungkapkam ide atau pendapat mereka dalam "dinding" Edmodo (Monalisa, 2013).

Edmodo memiliki bentuk seperti facebook. Edmodo sangat tepat digunakan untuk mengajarkan kemampuan menulis, khususnya mengajarkan Genre-Based Approach. Siswa memberikan persepsi positif dan negatif dalam menggunakan Edmodo dalam proses pembelajaran menulis. Menggunakan Edmodo merupakan pengalaman baru untuk mereka, sehingga ketika pertama kali menggunakan Edmodo mereka menemui kendala. Namun mereka dapat mengunduh materi yang diberikan oleh guru dalam fitur library yang ada dalam Edmodo. Mereka juga merasakan bahwa menggunakan Edmodo sangat mudah dan sederhana serta mereka termotivasi dalam menulis menggunakan Edmodo. Mereka juga dapat berkomunikasi dengan guru dan teman meskipun terkendala dengan Bandwith (Purnawarman, Susilawati, \& W, 2016).

Terdapat beberapa langkah dalam menggunakan Edmodo. Langkah-langkah tersebut dapat dilihat pada gambar 3 berikut.

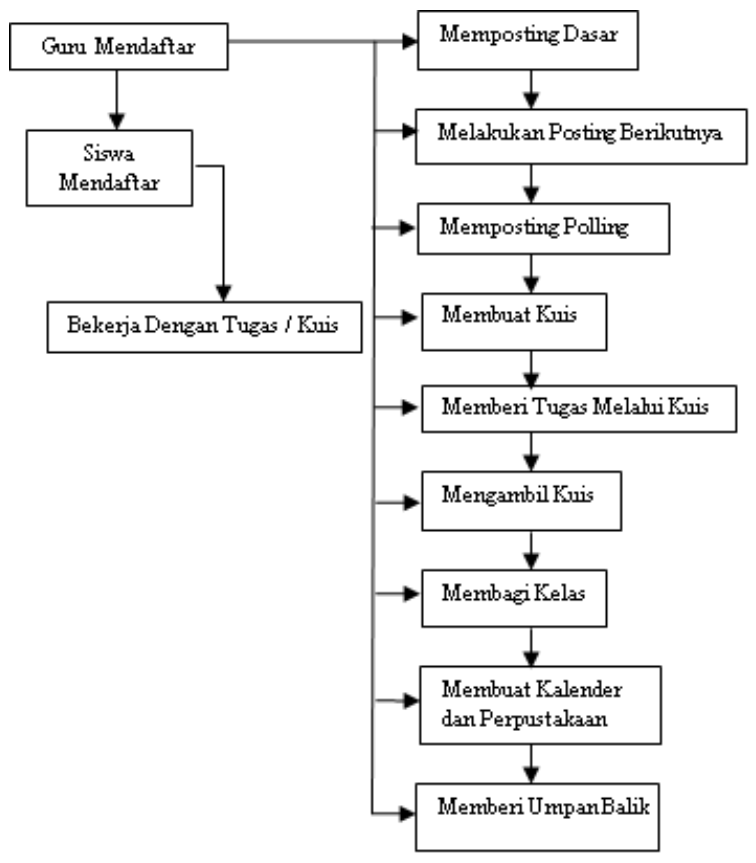

Gambar 3

Langkah-langkah Menggunakan

Edmodo (Evenddy \& Hamer, 2016) 
Edmodo mendorong keterlibatan siswa dan pembelajaran, preferensi siswa untuk menggunakan Edmodo terutama ditujukan untuk sumber daya, dukungan dan komunikasi seperti forum, diskusi dan juga untuk aktivitas online, siswa menemukan Edmodo sebagai sebuah platform pembelajaran sosial yang bagus dan mudah digunakan dan memungkinkan mereka menikmati bekerja di kelas online. (Balasubramanian \& Fukey, 2014)

\section{Penggunaan Edmodo dalam Pembelajaran Bahasa Inggris}

Dalam proses pembelajaran dan pengajaran bahasa Inggris, kemampuan berbicara adalah skill yang paling penting karena skill ini adalah dasar untuk berkomunikasi lisan (Oradee, 2012). Komunikasi lisan mengacu pada kemampuan untuk berkomunikasi secara verbal dan akurat dalam bahasa target. Seseorang dengan tingkat kemahiran lisan yang tinggi dapat menerapkan pengetahuan linguistik pada situasi atau konteks baru. Di sebagian besar pembelajaran bahasa Inggris, terutama dalam bahasa Inggris sebagai bahasa kedua / asing (ESL / EFL), instruktur sering dihadapkan dengan tugas yang menakutkan, yaitu membuat peserta didik mengatasi kecemasan mereka untuk berbicara dalam bahasa target. Tiga faktor utama yang berkontribusi terhadap kecemasan siswa adalah faktor budaya, faktor linguistik, dan faktor psikologis atau afektif. Kecemasan siswa biasanya dikaitkan dengan perasaan gelisah, cemas, ragu-ragu, dan frustrasi. Rasa ini mempengaruhi siswa dalam melakukan tugas di depan kelas dan membuat stres komunikatif. Nunan (Yusoff \& Ibrahim, 2012) mengemukakan bahwa siswa harus diberi kesempatan untuk berlatih karena mereka kebanyakan mendapatkan masalah dalam produksi bahasa target.
Akan lebih mudah bagi siswa EFL untuk diberikan lebih banyak waktu untuk merencanakan sebelum mereka mulai berbicara. Namun, karena keterbatasan waktu, praktik semacam itu hampir tidak mungkin dilakukan secara ekstensif di kelas.

Konsep pembelajaran bahasa menggunakan teknologi telah memungkinkan instruktur dan peserta didik bahasa untuk mengeksplorasi efektivitas pendekatan pembelajaran online. Kegiatan yang dimediasi komputer semacam itu menyediakan platform online untuk pelajar bahasa kedua untuk lebih lanjut melatih keterampilan bahasa mereka karena jam belajar dengan pertemuan tatap muka mereka agak terbatas. Jam belajar dengan pertemuan tatap muka yang terbatas berdampak pada peserta didik bahasa kedua yang ingin mengembangkan keterampilan berbicara mereka di kelas (Rodrigues \& Vethaman, 2015). Selain itu, Wichadee (2017) percaya bahwa, dalam blended learning, pembelajaran konvensional dilengkapi dengan penggunaan teknologi pembelajaran yang tepat. Penggunaan teknologi dengan metodologi pengajaran baru dapat menciptakan lingkungan belajar yang inovatif yang memungkinkan instruktur untuk mengatur pengajaran mereka dengan cara yang lebih efisien. Misalnya, waktu kelas dapat dihabiskan untuk mengajarkan konten yang cocok untuk pertemuan tatap muka.

\section{METODE PENELITIAN}

Penelitian ini merupakan penelitian kuantitatif deskriptif dengan teknik pengambilan datanya menggunakan angket. Penelitian diskriptif adalah penelitian mendiskripsikan hal-hal yang saat ini berlaku, sedangkan menurut jenis data dan cara pengolahannya yang angka dan dianalisis menggunakan uji statistik maka digolongkan dalam penelitian 
kuantitatif. Skor yang diperoleh kemudian dianalisis dengan menggunakan teknik statistik deskriptif.

Penelitian ini mulai dilaksanakan pada bulan Januari sampai dengan Mei 2019 di Program Studi Teknologi Pendidikan Universitas Baturaja. Variabel penelitian ini adalah respon mahasiswa terhadap pembelajaran bahasa inggris berbasis blended learning melalui edmodo.

Respon mahasiswa yang dimaksudkan dalam penelitian ini adalah setuju atau tidak setujunya mahasiwa di dalam mengimplementasikan pembelajaran bahasa inggris melalui edmodo. Populasi penelitian ini adalah mahasiswa Program Studi Teknologi Pendidikan yang masih aktif menempuh mata kuliah Bahasa Inggris pada tahun Akademik 2018/2019 berjumlah 44 orang. Sampel penelitian ini diambil dengan metode total sampling sehingga jumlah sampel adalah jumlah populasi yaitu 44 orang mahasiswa. Pengumpulan data menggunakan instrumen angket tertutup dengan pilihan setuju atau tidak setuju.

Pengolahan data pada penelitian ini dilakukan dengan mengolah data angket dengan menggunakan teknik statistik diskriptif kuantitatif yang selanjutnya dimaknai. Adapun butir instrumen pernyataan yang ada dalam angket adalah sebagai berikut.

\section{Tabel 1}

Pernyataan Respon Mahasiswa Terhadap Pembelajaran Bahasa Inggris Berbasis Blended learning Melalui Edmodo

\begin{tabular}{ll}
\hline No & \multicolumn{1}{c}{ Pernyataan } \\
\hline 1 & $\begin{array}{l}\text { Saya suka belajar bahasa inggris dengan menggunakan sistem pembelajaran } \\
\text { online seperti edmodo daripada belajar secara tatap muka dengan dosen. }\end{array}$ \\
2 & $\begin{array}{l}\text { Edmodo adalah media yang menarik dalam pembelajaran bahasa inggris. } \\
\text { Edmodo membuat saya bertanggungjawab dan disiplin dalam mengumpulkan } \\
\text { tugas. }\end{array}$ \\
4 & $\begin{array}{l}\text { Edmodo memberikan saya pengalaman/nuansa baru dalam pembelajaran } \\
\text { bahasa inggris. }\end{array}$ \\
5 & $\begin{array}{l}\text { Saya dapat menghemat waktu dalam mengerjakan dan mengumpulkan tugas } \\
\text { dengan edmodo. }\end{array}$ \\
& $\begin{array}{l}\text { Edmodo memudahkan saya dalam mengakses materi pembelajaran. } \\
\text { pembelajaran yang diupload melalui edmodo. }\end{array}$ \\
& $\begin{array}{l}\text { Saya lebih suka mengumpulkan tugas monolog/dialog dalam baha inggris } \\
\text { dengan mengupload video di Edmodo daripada tampil langsung di kelas saat } \\
\text { perkuliahan tatap muka dengan dosen. }\end{array}$ \\
\hline
\end{tabular}

\section{HASIL DAN PEMBAHASAN}

Data yang diperoleh dari angket yang telah disebar kepada 44 mahasiswa kemudian dianalisis dengan menghitung jumlah dan persentasenya. Hasil analisis tersebut dapat dilihat pada tabel berikut. 
Tabel 2

Hasil Analisis Respon Mahasiswa Terhadap Pembelajaran Bahasa Inggris Berbasis Blended Learning Melalui Edmodo

\begin{tabular}{ccc}
\hline \multirow{2}{*}{ PERNYATAAN } & \multicolumn{2}{c}{ RESPON MAHASISWA } \\
\cline { 2 - 3 } 1 & SETUJU & TIDAK SETUJU \\
2 & 36,36 & 63,64 \\
3 & 97,73 & 2,27 \\
4 & 93,18 & 6,82 \\
5 & 95,45 & 4,55 \\
6 & 95,45 & 4,55 \\
7 & 86,36 & 13,64 \\
8 & 74,13 & 28,87 \\
RATA-RATA & $\mathbf{8 2} \%$ & $\mathbf{1 8} \%$ \\
\hline
\end{tabular}

Berdasarkan tabel tersebut diperoleh informasi mengenai respon mahasiswa terhadap 8 butir instrumen pernyataan yang memperlihatkan respon mahasiswa terhadap pembelajaran bahasa inggris berbasis blended learning berbasis edmodo.

Pertama, 36,36\% mahasiswa setuju untuk belajar bahasa inggris menggunakan sistem pembelajaran online seperti edmodo daripada belajar secara tatap muka, sedangkan 63,64\% mahasiswa menyatakan tidak setuju. Kedua, 97,73\% mahasiswa menyatakan setuju bahwa edmodo adalah media yang menarik dalam pembelajaran bahasa inggris dan hanya 2,27\% mahasiswa yang menyatakan tidak setuju. Ketiga, 93,18\% mahasiswa menyatakan setuju bahwa edmodo membuat mahasiswa bertanggungjawab dan disiplin dalam pembelajaran bahasa inggris dan hanya $6,82 \%$ mahasiswa yang tidak setuju. Keempat, 95,45\% mahasiswa setuju bahwa edmodo memberikan mahasiswa pengalaman/ nuansa baru dalam pembelajaran bahasa inggris dan hanya $4,55 \%$ mahasiswa yang tidak setuju.

Kelima, 95,45\% mahasiswa menyatakan bahwa mahasiswa dapat menghemat waktu dalam mengerjakan dan mengumpulkan tugas edmodo dan hanya $4,55 \%$ mahasiswa yang menyatakan tidak setuju. Keenam, 86,36\% mahasiswa meyatakan setuju bahwa edmodo memudahkan mahasiswa dalam mengakses materi pembelajaran dan $13,64 \%$ mahasiswa menyatakan tidak setuju. Ketujuh, $74,13 \%$ mahasiswa menyatakan setuju bahwa mahasiswa dapat meningkatkan pemahaman bahasa inggris melalui video pembelajaran yang diupload melalui edmodo sedangkan $28,87 \%$ menyatakan tidak setuju. Kedelapan, $\quad 77,27 \%$ mahasiswa menyatakan setuju untuk mengumpulkan tugas monolog/doalog dalam bahasa inggris dengan mengumpload video di edmodo daripada tampil langsung di kelas saat perkuliahan tatap muka dengan dosen.

Berdasarkan tabel 2 tersebut juga dapat disimpulkan bahwa respon mahasiswa terhadap pembelajaran bahasa inggris berbasis blended learning melalui edmodo adalah positif. Hal ini terlihat dari hasil rata-rata respon mahasiswa pada 8 pernyataan yang mencapai $82 \%$ setuju pada pembelajaran bahasa inggris berbasis blended learning melalui edmodo. 


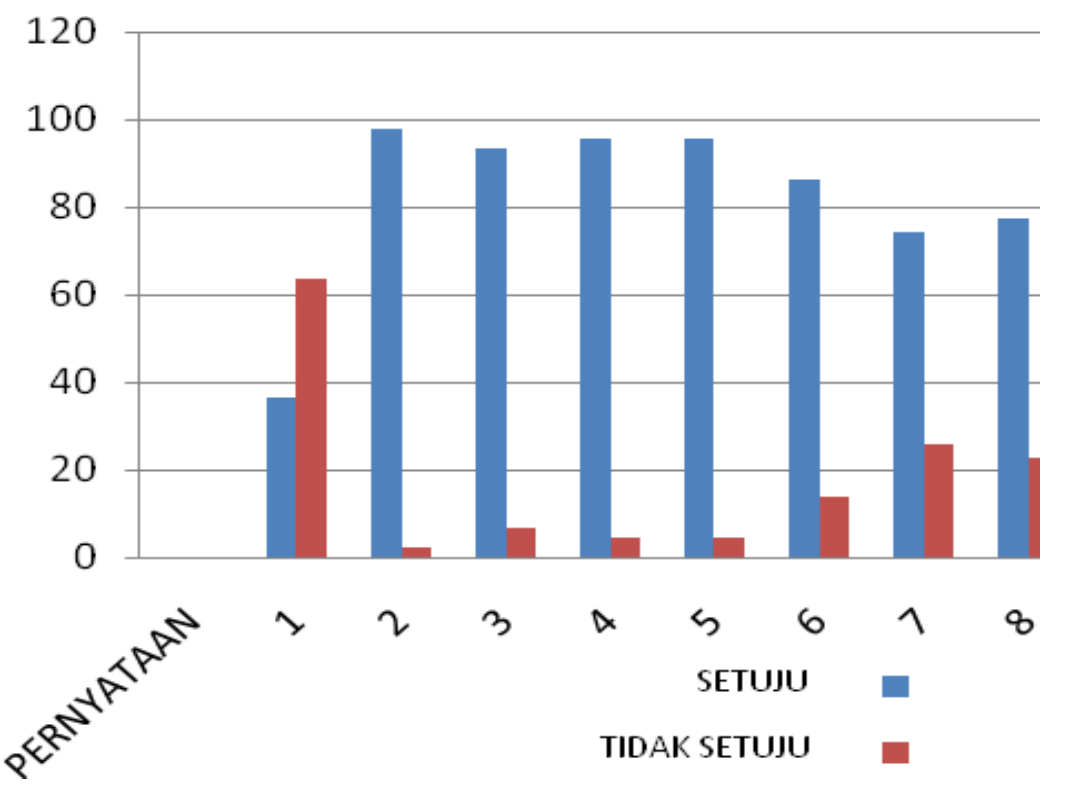

Gambar 4

Respon mahasiswa terhadap Pembelajaran Bahasa Inggris

Berbasis Blended learning Melalui Edmodo

Temuan penelitian menunjukkan bahwa respon mahasiswa terhadap pembelajaran bahasa inggris berbasis blended learning melalui edmodo di Program Studi Teknologi Pendidikan adalah baik (positif) dilihat dari aspek perbandingan dengan pembelajaran konvensional, kemenarikan, pembentukan karakter mahasiswa, inovasi pembelajaran, efisiensi waktu, kemudahan belajar, kecepatan pemahaman, dan penugasan.

Aspek perbandingan dengan pembelajaran konvensional, mahasiswa masih cenderung memilih pembelajaran konvensional karena kebiasaan diberikan secara langsung dari dosen. Sehingga ketika menemukan inovasi pembelajaran baru, mahasiswa cenderung lambat untuk memahami pemanfaatan dan penggunaanya. Mahasiswa juga merasa kesulitan ketika mengakses edmodo karena keterbatasan kuota atau akses internet. Hal ini sama halnya dengan temuan penelitian Agustina dan Ratnawati (Agustina \& Susanto, 2017) bahwa sebanyak $61,5 \%$ pendidik menemui hambatan saat menggunakan edmodo yaitu masalah koneksi jaringan internet yang tidak stabil.

Aspek kemenarikan, mahasiswa tertarik dan senang pada interface atau tampilan yang cenderung familiar terhadap keseharian mereka karena tampilannya mirip dengan tampilan facebook. Hal ini sesuai dengan hasil penelitian oleh Noni Agustina dan Ratnawati Susanto (Agustina \& Susanto, 2017) bahwa sebagian besar peserta didik sangat senang dan termotivasi menggunakan edmodo.

Aspek pembentukan karakter mahasiswa, fasilitas penugasan yang disediakan edmodo membantu mahasiswa untuk lebih bertanggungjawab dan disiplin dalam mengumpulkan tugas karena tugas telah diatur untuk diberikan waktu pengumpulan tugas. Jika mahasiswa terlambat mengumpulkan tugas maka akan tertera di sistem/akun edmodo dosen. Hal ini mendorong mahasiswa untuk disiplin dan tepat waktu dalam mengerjakan dan mengumpulkan tugas. Hal ini sesuai dengan penjelasan 
(Ekayati, 2018) bahwa dengan edmodo dosen dapat meminta mahasiswanya untuk untuk mengirim tugas sesuai deadline atau pengaturan waktu dimana isi dan kerahasiaannya sangat terjamin serta dapat membentuk sikap tanggung jawab mahasiswa.

Aspek inovasi pembelajaran, mahasiswa memperoleh model pembelajaran baru berbasis teknologi informasi dan komunikasi sehingga mahasiswa tidak gagap teknologi dan dapat lebih berkreasi dalam pembelajaran. Hal ini sesuai dengan pernyataan Rini Ekayati (Ekayati, 2018) bahwa model pembelajaran blended learning masih merupakan model pembelajaran yang baru di lingkungan FKIP UMSU.

Aspek efisiensi waktu, memberikan kemudahan pada mahasiswa dan dosen atas keterbatasan waktu. Pembelajaran yang tidak dapat dilakukan saat tatap muka dapat di ganti dengan pembelajaran virtual melalui edmodo. Sehingga waktu pertemuan yang kurang dapat diatasi dengan mengerjakan tugas dan mengumpulkannya melalui edmodo. Hal ini sesuai dengan hasil penelitian oleh Arief Wicaksono (Wicaksono, 2017) yang menyatakan bahwa edmodo sebagai kelas virtual memberikan kefleksibelan dalam waktu dan tempat.

Aspek kemudahan belajar, mahasiswa dapat belajar secara mandiri dengan mengunduh file-file kiriman tugas mahasiswa yang lain, termasuk mengenai materi video pembelajaran tentang monolog/dialog bahasa inggris. Mahasiswa dapat melihat secara berulang, mengamati, mempelajari secara seksama dibandingkan melihat langsung. Hal ini sesuai dengan temuan penelitian Ekayati (Ekayati, 2018) bahwa edmodo efektif untuk membantu mahasiswa memahami materi dengan mudah.

Aspek penugasan, mahasiswa cenderung menyukai penugasan melalui edmodo daripada tampil langsung didepan kelas. Hal ini juga menindaklanjuti kesulitan mahasiswa yang menghadapi kegugupan ketika monolog/dialog secara langsung di depan kelas. Hal ini sesuai dengan hasil penelitian Arief Wicaksono (Wicaksono, 2017) bahwa edmodo memberikan kesempatan lebih bagi orang yang merasa kesulitan mengungkapkan pendapatnya di kelas secara tatap muka.

Respon positif mahasiswa terhadap blended learning berbasis edmodo pada pembelajaran bahasa inggris ini memperlihatkan penerimaan inovasi pembelajaran dengan teknologi baru pada pembelajaran bahasa inggris. Hal ini sesuai dengan temuan penelitian sebelumnya oleh Wichadee (Wichadee S., 2017) yang menyatakan bahwa "This is probably because they believed that Edmodo helped them improve their language proficiency. The finding was also in accordance with the highest mean score of the response which stated that Edmodo has a great benefit in improving listening skill through the audio files uploaded.". Wichadee menyatakan bahwa alasan respon positif tersebut adalah kepercayaan mahasiswa bahwa edmodo membantu mahasiswa meningkatkan kemahiran bahasa mereka yang ditegaskan pada temuan tentang meningkatnya keterampilan mendengarkan melalui file audio yang diunggah. Hal ini senada dengan temuan peneliti bahwa Edmodo mampu membantu mahasiswa untuk meningkatkan pemahaman bahasa inggris melalui video pembelajaran yang diupload melalui edmodo. Hanya saja hasil positif dari butir pernyataan 2 dan 7 berbanding terbalik dengan hasil pernyataan 1 yang hanya $36,36 \%$ setuju untuk menerapkan blended learning dengan edmodo. Peneliti menemukan informasi bahwa hal tersebut dikarenakan kesulitan mahasiswa untuk mengakses 
internet sebagai modal utama menerapkan blended learning melalui edmodo.

Hasil penelitian ini dapat menjadi dasar bagi peneliti untuk menyelenggarakan pembelajaran yang inovatif dan kreatif khususnya pengembangan pembelajaran blended learning berbasis edmodo.

\section{E. KESIMPULAN}

Sebanyak $82 \%$ mahasiswa setuju pada pembelajaran bahasa inggris berbasis blended learning melalui edmodo. Berdasarkan hasil temuan penelitian tersebut disimpulkan bahwa respon mahasiswa Program Studi Teknologi Pendidikan FKIP Universitas Baturaja terhadap pembelajaran bahasa inggris berbasis blended learning melalui edmodo tergolong positif atau baik. Hal ini memperlihatkan bahwa edmodo menjadi media yang disukai peserta didik.

Meskipun temuan penelitian menyatakan respon mahasiswa positif atau baik terhadap pembelajaran bahasa inggris berbasis blended learning melalui melalui edmodo, namun sebagai catatan bahwa mahasiswa masih terkendala mengenai akses internet yang kadang terbatas dimiliki oleh mahasiswa.
Dengan demikian, dosen di Universitas Baturaja, khususnya dosen mata kuliah bahasa inggris yang akan mengembangkan keilmuaannya dapat menggunakan, memanfaatkan atau mengembangkan blended learning berbasis android dalam pembelajaran. Hal ini juga dapat dijadikan variasi dan inovasi pembelajaran bahasa inggris sehingga pembelajaran tidak monoton dan dapat memberikan semangat belajar mahasiswa, serta mampu membantu keterbatasan waktu dan tempat.

\section{DAFTAR PUSTAKA}

Agustina, N., \& Susanto, R. (2017, September). Persepsi Guru Terhadap Pengembangan Profesionalisme Melalui Pelatihan Media Pembelajaran Berbasis Edmodo. In Seminar Nasional Pendidikan Teknik Informatika (SENAPATI) (No. 7).

Balasubramanian, K., Jaykumar, V., \& Fukey, L. N. (2014). A study on "Student preference towards the use of Edmodo as a learning platform to create responsible learning environment". Procedia-Social and Behavioral Sciences, 144, 416-422.

Bencheva, N. (2010). Learning Styles and E-Learning Face-to-Face to the Traditional Learning. НАУЧНИ ТРУДОВЕ НА РУСЕНСКИЯ УНИВЕРСИТЕТ , 63-67.

Ekayati, R. (2018). Implementasi Metode Blended learning Berbasis Aplikasi Edmodo. Jurnal EduTech Vol. 4 No.2, 50-56.

Ekmekçi, E. (2016). Integrating Edmodo into foreign language classes as an assessment tool. Participatory Educational Research (PER), 1(1), 1-11.

Evenddy, S. S., \& Hamer, W. (2016). Edmodo As A Media to Teach Vocabulary. J. English 
Lang. Stud., vol. 1, no. 1, 26-34.

Hamad, M. (2015). Blended learning Outcome vs Traditional learning Outcome. International Journal on Studies in English Language and Literature (IJSELL). Vol. 3 Issue 4 , 7578.

Harmer, J. (2014). The practice of English language teaching. UK: Pearson/Longman.

Lalima, D. K., \& Dangwal, K. L. (2017). Blended learning: An innovative approach. Universal Journal of Educational Research, 5(1), 129-136.

Mokhtar, F. A. (2017). Recognizing Possible Limitations of E-Learning Through Edmodo. Proceedings of the ICECRS, 1(1).

Monalisa, \& H, A. (2013). Monalisa and H. Ardi, "Using Edmodo Educational Social Network in Teaching English for High School Sudents. J. English Lang. Teach.vol. 2, no. 1, , 220-225,.

Oradee, T. (2012). Developing Speaking Skills Using Three Communicative Activities (Discussion, Problem-Solving, and Role-Playing). International Journal of Social Science and Humanity, 2(6) , 533-535.

Pemerintah Republik Indonesia, (2010). Peraturan Pemerintah Republik Indonesia Nomor 17 tahun 2010 tentang Pengelolaan dan Penyelenggaraan Pendidikan. Jakarta

Purnawarman, P., Susilawati, \& W, S. (2016). "The Use of Edmodo in Teaching Writing in A Blended learning Setting,. Indones. J. Appl. Linguist., vol. 5, no. 2 , 242-252.

Redman, C., \& Trapani, F. (2012). Experiencing new technolog: Exploring pre-service teacher's perseptions and reflections upon the affordances of social media. AARE APERA International COnference I. Sydney Australia.

Rizkiyah, A. (2015). Blended learning Untuk Meningkatkan Hasil Belajar SiswaPada Mata Pelajaran Ilmu Bangunan di Kelas X TGB SMK Negeri 7 SURABAYA. Jurnal Kajian Pendidikan Teknik Bangunan Vol 1 Nomer 1/JKPTB/15, 40 - 49.

Rodrigues, P., \& Vethamani, M. (2015). The impact of blended learning in the development of speaking skill. Journal of Interdisclipnary Research in Education (JIRE) , 43-67.

Rulviana, V. (2018). Implementasi Media Edmodo dalam Mata Kuliah Pengembangan Kurikulum Sekolah Dasar. JURNAL REFLEKSI EDUKATIKA 8 (2) p-ISSN: 20879385 e-ISSN: 2528-696X, 205-208.

Sjukur, S. B. (2012). Pengaruh Blended learning Terhadap Motivasi Belajar dan Hasil Belajar Siswa Tingkat SMK. Jurnal Pendidikan Vokasi, Vol 2, Nomor 3, 368-378.

Wicaksono, A. (2017). Pengalaman E-Learning secara Penuh : Penggunaan Edmodo dalam Kelas Virtual. BACA: Jurnal Dokumentasi dan Informasi, 38 (1), 63-79.

Wichadee, S. (2017). A development of the blended learning model using edmodo for maximizing students' oral proficiency and motivation. iJET, 12(2) , 137-154.

Witherspoon.A. (2011). Edmodo...A learning Management System.

Yusoff, Z., \& Ibrahim, H. (2012). Teaching public speaking in a blended learning environment. International Journal of Social Science and Humanity, 2(6) , 573-576. 